\title{
Canada pours funds into health research
}

The newly created Canadian Institutes of Health Research (CIHR) has signalled in its first round of funding that it will keep its promise to support "innovative interdisciplinary ways to conduct research".

The agency announced last week that it will distribute Can $\$ 64$ million (US $\$ 43$ million) across nearly 500 diverse research projects, involving some 600 researchers in 100 different institutions.

The CIHR's budget over the next three years is effectively twice that of the Medical Research Council of Canada, which the CIHR replaced last June (Nature 405, 722; 2000) - and the new agency considerably broadens the scope of health research in Canada.

Many of the projects are on a scale that Canadian researchers have not previously enjoyed. Nineteen Interdisciplinary Health Research Teams (IHRTs), comprising more than 500 investigators in 91 institutes across Canada and internationally, will share Can\$15.5 million.

These teams will undertake research projects on such topics as the process of ageing; opiate addiction; breast-cancer susceptibility; and a genetic, epidemiological and population-based approach to the impact and control of colorectal cancer.

A further 19 large-scale multidisciplinary projects have been funded under the Community Alliances for Health Research (CAHR) programme, which aims to foster excellence in research of relevance to com-

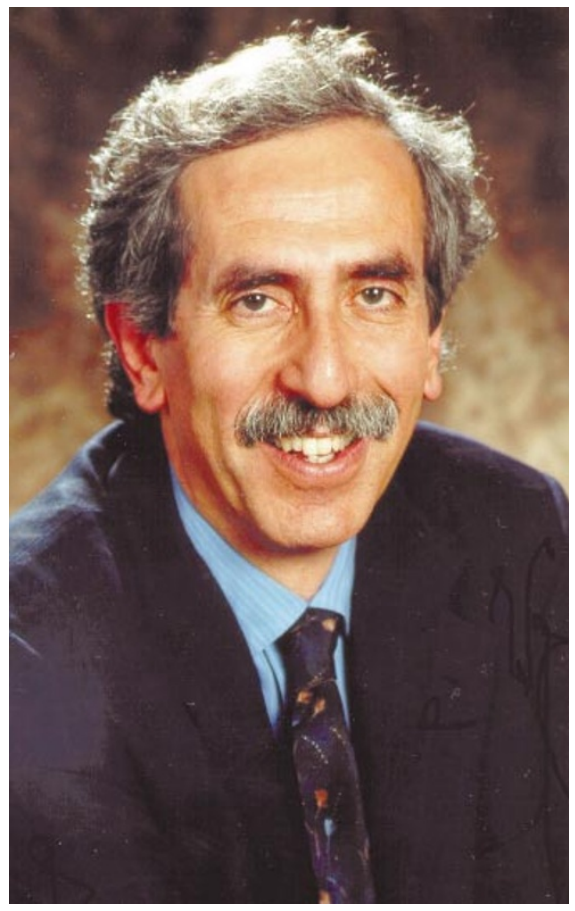

Stand and deliver: awards will make Canada 'the place to be' for health research, says Bernstein.

munity groups and agencies in biomedical and clinical research, and in health services generally. These projects will include research into community genetics, women's unpaid care-giving, chronic illness in rural healthcare systems, and marine and coastal workplace health and safety.

Funds were also approved for clinical trials, equipment and maintenance grants. Pilot projects in the national Genomics Research Program include a project at the University of Toronto to develop a rapid 'gene-trapping' method. Research grants are also being awarded under the federal government's HIV/AIDS strategy and the Health Canada/CIHR research initiative on hepatitis $\mathrm{C}$.

Robert S. Bell, an IHRT recipient at Mount Sinai Hospital, Toronto, says the programme has given himself and his colleagues "a unique opportunity" to bring together the three major centres in Canada for musculoskeletal cancers, and to combine clinical information with basic biology.

Before the CIHR was set up, says Bell, "there was no agency that would allow us to bring together patient information, tumour specimens, basic science information, clinical information and clinical outcomes and put that together into a big database that lets us to go from the patient to the laboratory and back again."

In a message to Canadian researchers, CIHR president Alan Bernstein said the awards demonstrate the CIHR's commitment to transform research in Canada.

"If we establish the right balance between investigator-initiated and strategic research, along with the right process to develop the right initiatives," said Bernstein, "I am convinced that we will be able to create [an] environment that will make Canada 'the place to be' for health research in the twentyfirst century." 